\title{
Anatomical Study of the Infrapatellar Branch of the Saphenous Nerve with Applications to Knee Surgery
}

\author{
Estudio Anatómico de la Rama Infrapatelar del Nervio \\ Safeno con Aplicaciones a la Cirugía de Rodilla
}

\author{
Ricardo Berriel Mendes ${ }^{1}$; Victor Hugo Faria Laranja ${ }^{1}$; Sheijy Sergio Vieira Mogami ${ }^{1}$; Max Rogerio Freitas Ramos ${ }^{1}$; \\ Lucas Alves Sarmento Pires²; Leonardo de Oliveira Figueiredo ${ }^{3}$ \& Marcio Antonio Babinski ${ }^{2}$
}

\begin{abstract}
MENDES, R. B.; LARANJA, V. H. F.; MOGAMI, S. S. V.; RAMOS, M. R. F.; PIRES, L. A. S.; FIGUEIREDO, L. O. \& BABINSKI, M.A. Anatomical study of the infrapatellar branch of the saphenous nerve with applications to knee surgery. Int. J. Morphol., 37(4):1258$1261,2019$.

SUMMARY: The infrapatellar branch of the saphenous nerve is a cutaneous nerve that innervates the area surrounding the patella and contributes to the peripatellar plexus. This nerve is target to iatrogenic injuries during a great deal of knee procedures, such as tendon harvesting, total knee arthroplasty and medial arthroscopic approaches to the knee. Lesion to this nerve can produce sensorial loss at its innervation territory. The study conducted herein aims to observe the anatomical aspects of the infrapatellar branch in cadaveric specimens. The infrapatellar branch of the saphenous nerve of 40 male cadavers was dissected with the purpose of identifying the number of branches, its relation with the patella, tibial tuberosity and sartorius muscle. The nerve was dissected and several measurements were performed with the aid of a digital caliper. Statistical analysis was performed with the MedCalc 16.1 software. The infrapatellar branch of the saphenous nerve was present in $100 \%$ of the sample. Its mean distance from its origin to its branching point was $16.35 \pm 6.48$ $\mathrm{mm}$ on the right and $21.94 \pm 4.31 \mathrm{~mm}$ on the left, with statistically significant differences $(\mathrm{p}<0.05)$. A relatively safe zone for surgery was observed on the superior and medial aspect of the patella, which received less branches.
\end{abstract}

KEY WORDS: Infrapatellar branch; Saphenous nerve; Knee surgery; Safe zones; Iatrogenic injury.

\section{INTRODUCTION}

Total knee arthroplasty is one of the most performed procedures in the world. However, this procedure, along with anterior cruciate ligament reconstruction, hamstring tendon harvest and medial meniscus surgery can often cause iatrogenic injury to the infrapatellar branch of the saphenous nerve (IPBSN), with rates ranging from $22.2 \%$ to $69 \%$ of patients (Koch et al., 2017; Ochiai et al., 2017; Henry et al., 2018). Furthermore, other procedures such as medial arthroscopic approaches and complementary posteromedial arthrotomies can cause injury to this nerve (Koch et al.).

The IPBSN is a sensorial nerve that innervates the skin surrounding the patella. Its injury can often lead to hypoesthesia, dysaesthesia, painful neuroma and reflex sympathetic dystrophy. Despite the lack of functional loss, these symptoms can often cause discomfort to the patient and dissatisfaction with the procedure, thus, these injuries are a liability to the surgeon and the hospital (Ochiai et al.; Ruffilli et al., 2017).

Several studies observed that the direction of the incision may reduce the probability of such injuries (Henry et al.; Mousavi et al., 2018). However, other studies observed that the incision technique did not influence clinical outcome or patient satisfaction after ACL reconstruction (Grassi et al., 2018).

In addition, studies have aimed to assess the position of the IPBSN in order to observe patterns that might indicate a safer space for incision, although it is known that the IPBSN is highly variable (Kerver et al., 2013; Kalthur et al., 2015; Koch et al.; Henry et al.).

\footnotetext{
${ }^{1}$ Hospital Universitário Gaffrée e Guinle, Universidade Federal do Estado do Rio de Janeiro, Rio de Janeiro, Brasil.

${ }^{2}$ Programa de Pós Graduação em Ciências Médicas, Universidade Federal Fluminense, Niterói, Brasil.

${ }^{3}$ Hospital Municipal Salgado Filho, Rio de Janeiro, Brasil.
} 
As such, the work presented herein aims to address the anatomical and surgical study of the IPBSN with the purpose of further enhancing data regarding the IPBSN and to assess a possible safe zone with the purpose of reducing iatrogenic injuries during aforementioned procedures in a large cadaveric sample.

\section{MATERIAL AND METHOD}

This work complies with the provisions of the Declaration of Helsinki, made in 1995 (as revised in Edinburgh, 2000).

20 male cadavers fixated in a $10 \%$ formalin solution were dissected with the purpose of identifying the IPBSN and its branches. Then, the IPBSN was thoroughly dissected and the following measurements were performed (Fig. 1):

a) From the medial margin of the patella to the IPBSN (M1).

b) From its origin to its branching point (M2).

c) From the apex of the patella to the largest branch of the IPBSN (M3).

d) From the largest branch of the IPBSN to the tibial tuberosity (M4).

The IPBSN was classified according to its relation with the sartorius muscle (Ackmann et al., 2014). The number of branches, point of origin and point of branching were documented. The direction of the smaller branches were observed and documented as well.

The statistical analysis was performed using MedCalc version 16.8 and IBM SPSS 21. Data were analyzed using elements of descriptive statistics (mean, standard deviation). For comparison of measurements between sides, the tstudent's test was used and the value of $p<0.05$ was considered significant for all analysis.

\section{RESULTS}

The IPBSN was present in $100 \%$ of the sample.

The mean distance of the IPBSN to the medial margin of the patella (M1) was $10.11 \pm 3.47 \mathrm{~mm}$, without significant side differences $(\mathrm{p}>0.05)$. The mean distance from its origin to its branching point (M2) was $16.35 \pm 6.48 \mathrm{~mm}$ on the right and $21.94 \pm 4.31 \mathrm{~mm}$ on the left, with statistically significant differences $(\mathrm{p}<0.05)$.
The mean distance from the apex of the patella to the largest branch of the IPBSN (M3) was $4.66 \pm 1.23 \mathrm{~mm}$, without significant side differences $(\mathrm{p}>0.05)$, and the mean distance from the largest branch of the IPBSN to the tibial tuberosity (M4) was $7.13 \pm 3.96 \mathrm{~mm}$, without significant differences regarding side $(\mathrm{p}>0.05)$.

Usually, the IPBSN originated 3 branches (70\%), while in $22.5 \%$ the nerve originated only 2 . In $7.5 \%$ of the sample the IPBSN gave 4 branches or more. These smaller branches ran obliquely between the tibial tuberosity and the apex of the patella.

The IPBSN pierced the sartorius muscle (Fig. 1) in $32.5 \%$ of cases and passed anteriorly to this muscle in 67.5 $\%$ of cases (Fig. 2). This data is summarized in Table I.

It was observed a variable disposition of the largest branch of the IPBSN in relation to the apex of the patella. In $15 \%$ of the samples, the nerve was situated distally to the apex and closer to the tibial tuberosity, while in $85 \%$ it was located proximal to the apex of the patella and away from the tibial tuberosity. No large branches were found below the tibial tuberosity.

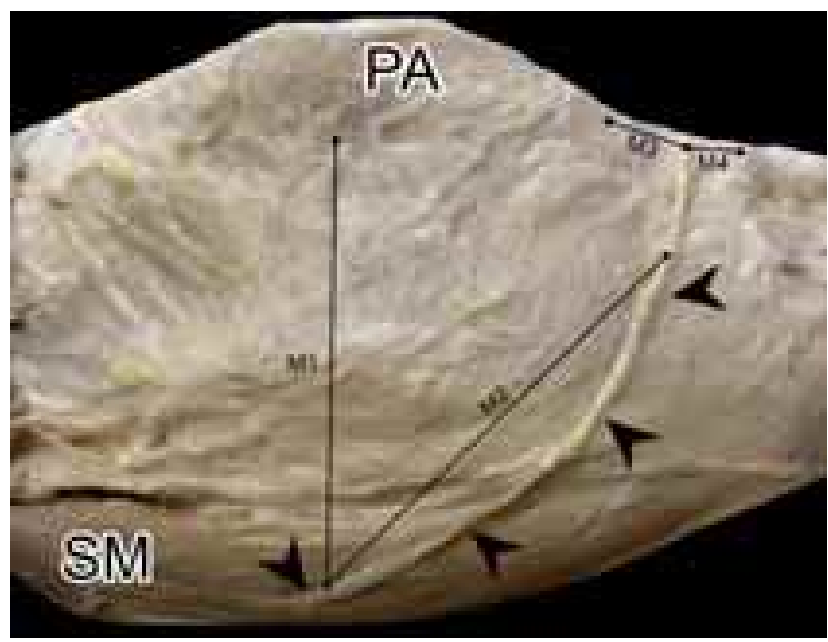

Fig. 1. The infrapatellar branch of the saphenous nerve (black arrowheads) piercing the sartorius muscle (SM). The patella can also be observed (PA). The measurements performed are also depicted.

Table I. Number of branches of the IPBSN and its relationship with the sartorius muscle in the studied sample.

\begin{tabular}{llll}
\hline $\begin{array}{l}\text { Number of } \\
\text { branches }\end{array}$ & $\%$ & $\begin{array}{l}\text { Relationship with the } \\
\text { sartorius muscle }\end{array}$ & $\%$ \\
\hline 1 & 0 & Anterior type & 67.5 \\
2 & 22.5 & Piercing type & 32.5 \\
3 & 70 & Posterior type & 0 \\
4 & 7.5 & - & - \\
\hline
\end{tabular}




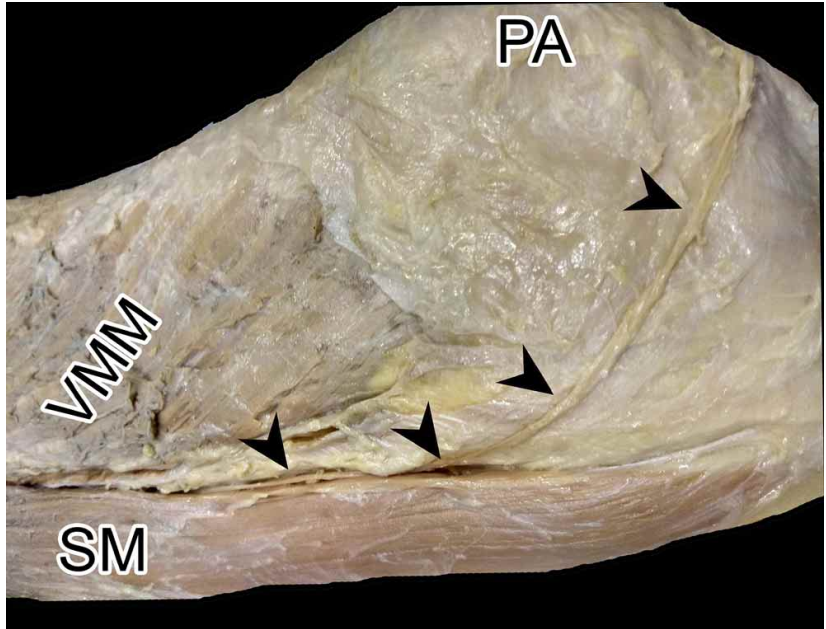

Fig. 2. The infrapatellar branch of the saphenous nerve (black arrowheads) running over the anterior margin of the sartorius muscle (SM) can be seen. The vastus medialis muscle (VMM) and the patella (PA) are also shown.

\section{DISCUSSION}

The saphenous nerve is a sensitive nerve that arises from the posterior division of the femoral nerve (L3-L4). It is the largest and longest cutaneous branch. As it leaves the adductor canal, this nerve gives origin to the IPBSN, which may pierce the sartorius muscle, arches beneath the patella to its lateral side and gives numerous branches to the adjacent skin (Testut \& Latarjet, 1958).

Our study observed that the IPBSN had a variable point of branching. Furthermore, these aspects were asymmetrical in most of the cases $(\mathrm{p}<0.05)$.

The IPBSN usually gave 2 to 3 branches, while its first branch was the largest one and arched laterally to find the subcutaneous tissue below the patella, this branch also originated smaller nervous filaments that ran towards the lateral aspect of the patella (to form the peripatellar plexus with the lateral femoral cutaneous nerve). Furthermore, we observed three different anatomical relations of this larger branch with respect to the apex of the patella, and the most prevalent one was where the nerve was placed very near the bone $(85 \%)$ and away from the tibial tuberosity.

The other main branches of the IPBSN were small and situated on the medial and inferior aspect of the patella. This finding is consistent with other studies and anatomical textbooks (Testut \& Latarjet; Kalthur et al.). However, the study by Gali et al. (2014) only found 1 to 2 branches on the knee. Although the authors commented the difficulty in dissecting this nerve which may have influenced the dissection.
Despite that, other studies observed the same number of branches in a cadaveric sample (Kalthur et al.). Their paper also had similar results regarding the relation with the sartorius muscle (anterior type) and the distance between the medial margin of the patella and the IPBSN.

In contrast, the study conducted by Arthornthurasook \& Gaew-Im (1988) observed that the most common pattern was the posterior type, in which the IPBSN crossed the posterior margin of the sartorius muscle, our study did not observe this pattern in the studied sample.

The IPBSN is known to be a variable nerve, although our study did not observe any anatomical variations besides differences in point of origin and branching, which were not constant among our sample. There were no anatomical variations regarding duplication, absence or incomplete trajectory.

Regarding the incisions performed during tendon harvesting procedures, most of the studies observed that the oblique type was the less likely to cause injury on the IPBSN (Pekala et al., 2017; Ruffilli et al.; Grassi et al.; Henry et al.). This is probably due to the direction of the smaller branches, as they ran obliquely towards the tibial tuberosity, a disposition found in the present study.

Our work further adds to the literature the importance of studying the IPBSN patterns with the purpose to find a possible safe zone for incision. However, the lack of studies with this purpose, the high variability of the IPBSN and the small sample of surgical, cadaveric and clinical studies makes it difficult to compare results as previously stated by Henry et al.

Another aspect that may cause difficulty in addressing this nerve is due to the fact that it can be altered by knee mobility: the IPBSN moves distally with flexion, as such, incisions should be performed with the patient's knee flexed, as to avoid iatrogenic injuries (Tifford et al., 2000).

We believe that the first branch of the IPBSN is the most concerning, as it is the largest and it can arch laterally near the apex of the patella or $2 \mathrm{~cm}$ below it. This branch began its route near the medial aspect of the tibial plateau, thus, incisions should be performed according to this anatomical relation.

The study performed by Kerver et al. observed that the safest zone was near the entry point of the IPBSN towards the knee (after passing by the Sartorius muscle) or over the inferior margin of the patella, although the authors employed an automatic mapping tool software. Despite that, their results were similar to ours, as there was less branches or no branches of this nerve in the aforementioned regions. 
Mochida \& Kikuchi (1995) pointed out that the area 3 $\mathrm{cm}$ from the medial margin of the patella (middle third) and the area $1 \mathrm{~cm}$ from the medial margin of the patella (lower third/ apex) was relatively safe for incision. This also goes according to our study, which observed a safe zone in this area, although $1 \mathrm{~cm}$ from the medial margin of the patella (middle third).

CONCLUSIONS. Despite being a variable nerve, data regarding its anatomical relationships should be investigated in order to better predict the outcomes and avoid iatrogenic injuries, as they are fairly common during several procedures.

It was observed that the safer space to perform incisions is the region near the medial margin of the middle third of the patella, as it received less branches. More studies should be performed to verify patterns among patients and cadaveric samples.

MENDES, R. B.; LARANJA, V. H. F.; MOGAMI, S. S. V.; RAMOS, M. R. F.; PIRES, L. A. S.; FIGUEIREDO, L. O. \& BABINSKI, M. A. Estudio anatómico de la rama infrapatelar del nervio safeno con aplicaciones a la cirugía de rodilla. Int. J. Morphol., 37(4):1258-1261, 2019.

RESUMEN: La rama infrapatelar del nervio safeno es un nervio cutáneo que inerva el área que rodea la patela y contribuye al plexo peripatelar. Este nervio es objeto de lesiones iatrogénicas durante una gran cantidad de procedimientos de rodilla, como la extracción de tendones, la artroplastía total de rodilla y los abordajes artroscópicos mediales de la rodilla. La lesión de este nervio puede producir pérdida sensorial en su territorio de inervación. El estudio realizado aquí tiene como objetivo observar los aspectos anatómicos de la rama infrapatelar en muestras de cadáveres. La rama infrapatelar del nervio safeno de 40 cadáveres masculinos se disecó con el propósito de identificar el número de ramas, su relación con la patela, la tuberosidad tibial y el músculo sartorio. Se disecó el nervio y se realizaron varias mediciones con la ayuda de un calibrador digital. El análisis estadístico se realizó con el software MedCalc 16.1. La rama infrapatelar del nervio safeno estaba presente en el $100 \%$ de las muestras. La distancia media desde su origen hasta su punto de rami-

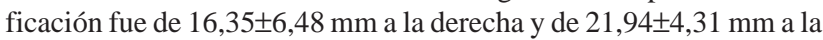
izquierda, con diferencias estadísticamente significativas ( $\mathrm{p}<0,05)$. Se identificó una zona relativamente segura para la cirugía en el aspecto superior y medial de la patela, que recibió menos ramas.

PALABRAS CLAVE: Rama infrapatelar; Nervio safeno; Cirugía de rodilla; Zonas seguras; Lesión iatrogénica.

\section{REFERENCES}

Ackmann, T.; Von Düring, M.; Teske, W.; Ackermann, O.; Muller, P. \& Von Schulze Pellengahr, C. Anatomy of the infrapatellar branch in relation to skin incisions and as the basis to treat neuropathic pain by cryodenervation. Pain Physician, 17(3):E339-48, 2014.
Arthornthurasook, A. \& Gaew-Im, K. Study of the infrapatellar nerve. Am. J. Sports Med., 16(1):57-9, 1988.

Gali, J. C.; Resina, A. F.; Pedro, G.; Neto, I. A.; Almagro, M. A.; da Silva, P. A. \& Caetano, E. B. Importance of anatomically locating the infrapatellar branch of the saphenous nerve in reconstructing the anterior cruciate ligament using flexor tendons. Rev. Bras. Ortop., 49(6):625-9, 2014.

Grassi, A.; Perdisa, F.; Samuelsson, K.; Svantesson, E.; Romagnoli, M.; Raggi, F.; Gaziano, T.; Mosca, M.; Ayeni, O. \& Zaffagnini, S. Association between incision technique for hamstring tendon harvest in anterior cruciate ligament reconstruction and the risk of injury to the infra-patellar branch of the saphenous nerve: a meta-analysis. Knee Surg. Sports Traumatol. Arthrosc. 26(8):2410-23, 2018.

Henry, B. M.; Tomaszewski, K. A.; Pekala, P. A.; Graves, M. J.; Pekala, J. R.; Sanna, B. \& Mizia, E. Oblique incisions in hamstring tendon harvesting reduce iatrogenic injuries to the infrapatellar branch of the saphenous nerve. Knee Surg. Sports Traumatol. Arthrosc., 26(4):1197-203, 2018.

Kalthur, S. G.; Sumalatha, S.; Nair, N.; Pandey, A. K.; Sequeria, S. \& Shobha, L. Anatomic study of infrapatellar branch of saphenous nerve in male cadavers. Ir. J. Med. Sci., 184(1):201-6, 2015.

Kerver, A. L.; Leliveld, M. S.; den Hartog, D.; Verhofstad, M. H. \& Kleinrensink, G. J. The surgical anatomy of the infrapatellar branch of the saphenous nerve in relation to incisions for anteromedial knee surgery. J. Bone Joint Surg. Am., 95(23):2119-25, 2013.

Koch, G.; Kling, A.; Ramamurthy, N.; Edalat, F.; Cazzato, R. L.; Kahn, J. L.; Garnon, J. \& Clavert, P. Anatomical risk evaluation of iatrogenic injury to the infrapatellar branch of the saphenous nerve during medial meniscus arthroscopic surgery. Surg. Radiol. Anat., 39(6):611-8, 2017.

Mochida, H. \& Kikuchi, S. Injury to infrapatellar branch of saphenous nerve in arthroscopic knee surgery. Clin. Orthop. Relat. Res., (320):88-94, 1995.

Mousavi, H.; Mohammadi, M. \& Aghdam, H. A. Injury to the infrapatellar branch of the saphenous nerve during ACL reconstruction with hamstring tendon autograft: a comparison between oblique and vertical incisions. Arch. Bone Jt. Surg., 6(1):52-6, 2018.

Ochiai, S.; Hagino, T.; Senga, S.; Yamashita, T.; Oda, K. \& Haro, H. Injury to infrapatellar branch of saphenous nerve in anterior cruciate ligament reconstruction using vertical skin incision for hamstring harvesting: risk factors and the influence of treatment outcome. J. Orthop. Surg. Res., 12(1):101, 2017.

Pekala, P. A.; Tomaszewski, K. A.; Henry, B. M.; Ramakrishnan, P. K.; Roy, J.; Mizia, E. \& Walocha, J. A. Risk of iatrogenic injury to the infrapatellar branch of the saphenous nerve during hamstring tendon harvesting: A meta-analysis. Muscle Nerve, 56(5):930-7, 2017.

Ruffilli, A.; De Fine, M.; Traina, F.; Pilla, F.; Fenga, D. \& Faldini, C. Saphenous nerve injury during hamstring tendons harvest: Does the incision matter? A systematic review. Knee Surg. Sports Traumatol. Arthrosc., 25(10):3140-5, 2017.

Testut, L. \& Latarjet, A. Tratado de Anatomía Humana. $8^{\text {th }}$ ed. Barcelona, Salvat, 1958.

Tifford, C. D.; Spero, L.; Luke, T. \& Plancher, K. D. The relationship of the infrapatellar branches of the saphenous nerve to arthroscopy portals and incisions for anterior cruciate ligament surgery. An anatomic study. Am. J. Sports Med., 28(4):562-7, 2000.

\section{Corresponding author:}

Professor Lucas Alves Sarmento Pires, MsC.

Fluminense Federal University

Morphology Department - Biomedical Institute

Rua Professor Ernani Mello, 101

São Domingos, Niterói

Rio de Janeiro

24210-150

BRAZIL

Email: lucaspires@id.uff.br
Received: 11-03-2019

Accepted: 10-06-2019 